\title{
ST
}

Science \& Technology

PAPER - OPEN ACCESS

Pengaruh Strategi Pembelajaran POGIL dengan Animasi Komputer Terhadap Motivasi dan Hasil Belajar Siswa SMA Pada Materi Pokok Stoikiometri
Author $\quad$ : Sri Saragih dkk.,
DOI $\quad: 10.32734 /$ st.v2i1.348
Electronic ISSN $\quad: 2654-7082$
Print ISSN $\quad: 2654-7074$

Volume 2 Issue 1-2018 TALENTA Conference Series: Science \& Technology (ST)

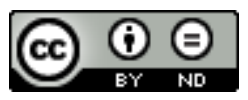

This work is licensed under a Creative Commons Attribution-NoDerivatives 4.0 International License.

Published under licence by TALENTA Publisher, Universitas Sumatera Utara

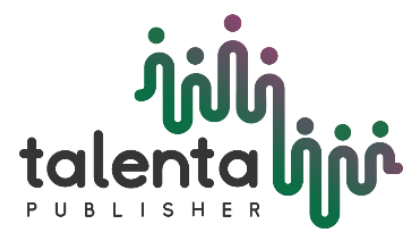




\section{Pengaruh Strategi Pembelajaran POGIL dengan Animasi Komputer Terhadap Motivasi dan Hasil Belajar Siswa SMA Pada Materi Pokok Stoikiometri}

\author{
Sri Wahyuna Saragih ${ }^{\mathrm{a} *}$, Mayang Sari $^{\mathrm{b}}$, Eddyanto $^{\mathrm{c}}$, Ramlan Silaban $^{\mathrm{d}}$ \\ ${ }^{a}$ Program Studi Farmasi, Universitas Cut Nyak Dhien Langsa, Aceh, Indonesia \\ ${ }^{a, b}$ Mahasiswa Program Doktor Universitas Sumatera Utara, Medan, Indonesia \\ ${ }^{c, d}$ Magister Pendidikan Kimia, Program Pascasarjana, Universitas Negeri Medan, Sumatera Utara, Indonesia
}

*yunasaragih@gmail.com

\begin{abstract}
Abstrak
Penelitian ini betujuan untuk mengetahui: 1) Apakah hasil belajar siswa yang diajar menggunakan pembelajaran POGIL animasi komputer lebih tinggi dibandingkan dengan siswa yang diajar menggunakan pembelajaran konvensional.2) Apakah motivasi belajar siswa yang diajar menggunakan pembelajaran POGIL animasi komputer lebih tiggi dibandingkan dengan siswa yang diajar menggunakan pembelajaran konvensional. 3) Apakah terdapat pengaruh motivasi yang ditimbulkan pada pembelajaran POGIL animasi komputer terhadap hasil belajar siswa pada materi pokok Stoikoimetri. Metode penelitian adalah metode eksperimen. Data penelitian yang dikumpulkan dari sampel adalah berupa belajar siswa yang diperoleh dari tes hasil belajar berupa pilihan berganda dan data motivasi belajar siswa yang diperoleh dari angket. Hipotesis diuji dengan uji beda nyata semu factorial 2 x 2 pada taraf signifikansi 0,05 serta menggunakan uji regresi dan korelasi . Hasil penelitian menunjukkan: 1) Hasil belajar siswa yang diajar menggunakan pembelajaran POGIL animasi komputer lebih tinggi dibandingkan hasil belajar siswa yang diajar menggunakan pembelajaran konvensional dengan $Z_{\text {hitung }}>Z_{\text {tabel }}$ yaitu, 6,51 > 1,71, 2) Motivasi belajar siswa yang diajar menggunakan pembelajaran POGIL animasi komputer lebih tinggi dibandingkan motivasi belajar siswa yang diajar menggunakan pembelajaran konvensional dengan $Z_{\text {hitung }}>Z_{\text {tabel }}$ yaitu, 6,10 > 1,71, 3) Terdapat Pengaruh motivasi yang ditimbulkan pembelajaran POGIL animasi komputer terhadap hasil belajar siswa pada materi pokok Stoikiometri dengan Fhitung $>$ $\mathrm{F}_{\text {tabel }}$ yaitu, 11,2 > 4,10 dan memberi kontribusi sebesar $72 \%$ terhadap hasil belajar.
\end{abstract}

Kata Kunci : POGIL, Animasi Komputer, Konvensional, Stoikiometri

\section{Pendahuluan}

Pelajaran kimia merupakan pelajaran yang menginformasikan teorinya berdasarkan eksperimen atau percobaan. Banyaknya siswa yang tidak menyukai kimia dikarenakan penguasaan materi dan konsep kimia yang kurang. Sulitnya pemahaman siswa tentang konsep kimia menimbulkan asumsi bahwa pelajaran kimia merupakan pelajaran yang sulit. Padahal penguasaan konsep kimia merupakan hal paling penting dalam pembelajaran kimia. Pembelajaran kimia lebih menekankan pada keterampilan berproses ilmiah dan keterampilan berpikir kritis [1]. Fenomena kesulitan belajar kimia ini juga diungkapkan oleh Butar butar dimana terdapat ketakutan siswa terhadap pelajaran kimia sehingga berdampak pada rendahnya hasil belajar kimia siswa [2].

Banyaknya konsep kimia yang bersifat abstrak yang harus diserap siswa dalam waktu relatif terbatas menjadikan ilmu kimia menjadi salah satu mata pelajaran yang sulit bagi siswa sehingga banyak siswa gagal dalam belajar kimia. Pada umumnya siswa cenderung belajar dengan hafalan daripada secara aktif mencari untuk membangun pemahaman mereka sendiri terhadap konsep kimia [3].

Hal ini dapat dilihat dari nilai kimia kelas X semester 1, 3 tahun terakhir di SMA Negeri 1 Paombeian Panei, 
Tabel 1. Data nilai rata-rata dan ketuntasan mata pelajaran kimia semester ganjil kelas X SMA Negeri Panombeian Panei

\begin{tabular}{ccc} 
Tahun Pelajaran & Nilai Rata-rata & KKM \\
$\mathbf{2 0 0 8 / 2 0 0 9}$ & 68,97 & 65,00 \\
\hline $\mathbf{2 0 0 9 / 2 0 1 0}$ & 67,70 & 65,00 \\
\hline $\mathbf{2 0 1 0 / 2 0 1 1}$ & 69,30 & 68,00 \\
\hline
\end{tabular}

Sumber : Arsip Tata Usaha SMA Negeri 1 Panombeian Panei

Hal ini sangat memerlukan model pembelajaran yang lebih bermakna, salah satunya menggunakan model POGIL (Process Oriented Guided-Inquiry Learning). POGIL merupakan strategi pembelajaran yang memberikan peluang untuk mengajar baik konten dan keterampilan proses kunci secara bersamaan. POGIL menekankan bahwa belajar adalah sebuah proses interaktif berpikir hati-hati, mendiskusikan ide-ide, pemahaman pemurnian, berlatih keterampilan, yang mencerminkan tentang kemajuan, dan menilai kinerja [4].

Pendekatan POGIL adalah salah satu dar iinkuiri terbimbing.POGIL menggunakan inkuiri terbimbing - siklus belajar eksplorasi, penemuan konsep dan aplikasi adalah dasar bagi banyak bahan dirancang dengan baik untuk siswa dan digunakan untuk membimbing siswa dalam membangun pengetahuan baru. Sangat penting bahwa guru, bertindak sebagai fasilitator, tahu terlebih dahulu hasil dari eksperimen [5].

Process Oriented Guided-inquiry learning (POGIL) adalah mengajarmetode yang didasarkan pada prinsip-prinsip konstruktivis yang memungkinkansiswa untuk belajar melalui interaksi kelompok dan masalahpemecahan. POGIL berbasis biasanya menggunakan latihan terstruktur.Latihan-latihan kelompok siswa, hadir dengan masalah dan panduanmereka melalui langkah-langkah yang diperlukan untuk mengatasi masalah tersebut. Siswakemudian menerapkan pemahaman mereka terhadap proses untuk masalah baru [6].

POGIL merupakan strategi instruksional yang menyediakan kesempatan untuk mengajarkan baik konten dan keterampilan proses secara bersamaan. POGIL menekankan bahwa belajar adalah sebuah proses interaktif berpikir hati-hati, mendiskusikan ide-ide, pemahaman pemurnian, berlatih keterampilan, yang mencerminkan tentang kemajuan, dan menilai kinerja.

Sebuah studi di Amerika yang diterbitkan sebelumnya membandingkan kinerja siswa kimia umum diajarkan menggunakan pendekatan tradisional yang selama periode 1990-1994 (n 420) kepada siswa diajarkan selama empat tahun berikutnya oleh instruktur yang sama, tetapi menggunakan pendekatan POGIL $(\mathrm{n}=485)$ [7]. Tingkat putus sekolah menurun dari 21,9\% (tradisional) menjadi 9,6\% (POGIL). Persentase siswa mendapatkan nilai A atau B meningkat dari $52 \%$ menjadi $64 \%$ motivasi untuk POGIL.

Berdasarkan uraian diatas, maka dianggap perlu dilakukan suatu perubahan cara mengajar kimia melalui suatu strategi pembelajaran yang lebih bermakna dan unggul yang dapat membangkitkan motivasi, daya kreativitas dan semangat belajar siswa agar mencapai hasil belajar yang memuaskan. Strategi pembelajaran POGIL (Process Oriented Guided-Inquiry Learning) mempunyai kekuatan dalam merancang tim belajar bahwa guru sebagai fasilitator bukan sebagai sumber informasi, siswa dibimbing melalui eksplorasi untuk membangun pemahaman, menggunakan konten disiplin untuk memfasilitasi pengembangan proses keterampilan penting termasuk berpikir tingkat tinggi dan kemampuan untuk belajar dan untuk menerapkan pengetahuan dalam konteks baru. Untuk mendapatkan hasil yang optimal dalam penggunaan strategi pembelajaran POGIL pada pelajaran kimia, akan diintegrasikan dengan animasi komputer, maka penulis berkeinginan melakukan penelitian bagaimana pengaruh pembelajaran POGIL (Process Oriented Guided-Inquiry Learning) menggunakan animasi komputer dalam meningkatkan hasil belajar kimia SMA, dibandingkan dengan pembelajaran konvensional. Judul penelitian ini adalah "Pengaruh Strategi Pembelajaran Process Oriented Guided-Inquiry Learning (POGIL) dengan Animasi Komputer Terhadap Motivasi Dan Hasil Belajar Siswa SMA Pada Materi Pokok Stoikiometri." 


\section{Metode Penelitian}

\section{Populasi dan Sampel}

Populasi dalam penelitian ini adalah seluruh siswa kelas X SMA tahun Ajaran 2011/2012. Karena keterbatasan waktu, dana, tenaga dan fasilitas untuk mendukung penelitian ini maka penelitian yang dilakukan hanyalah pada siswa SMA kelas X semester satu Tahun Ajaran 2011/ 2012 di SMA Negeri 1 Panombeian Panei Kabupaten Simalungun.

Jumlah seluruh siswa SMA kelas X semester satu Tahun Ajaran 2011/ 2012 di SMA Negeri 1 Panombeian Panei Kabupaten Simalungun adalah 80 orang. Sampel penelitian ini berdasarkan hasil pretest seluruh siswa tersebut. Sampel dikelompokkan dalam dua kelompok, dimana masing-masing kelompok terdiri dari jumlah siswa yang sama (40 orang) yang di upayakan homogen berdasarkan hasil pretest tersebut.

\section{Desain Penelitian}

Penelitian ini melibatkan 2 kelas eksperimen yang diberi perlakuan yang berbeda. Pada kelas eksperimen 1 diberi perlakuan pembelajaran POGIL dengan animasi komputer, pada kelas eksperimen 2 diberi perlakuan kontrol yaitu pembelajaran konvensional. Untuk melihat hasil belajar siswa pada eksperimen ini, diberikan tes pada siswa sebelum perlakuan (pretest) dan setelah perlakuan (posttest), dan untuk melihat motivasi belajar siswa diberikan angket motivasi setelah perlakuan eksperimen (posttest) Untuk lebih jelasnya disain penelitian ini diperlihatkan pada tabel 2

Tabel 2. Desain Penelitian

\begin{tabular}{ccccc}
\hline Kelas & Pretest & Perlakuan & Postest & Angket \\
\hline Kelas Eksperimen 1 & $\mathrm{T}_{1.1}$ & $\mathrm{~A}_{1.1 .}$ & $\mathrm{T}_{2.1}$ & $\mathrm{~A}_{2.1}$ \\
\hline Kelas Eksperimen 2 & $\mathrm{T}_{1.2}$ & $\mathrm{~A}_{1.2}$ & $\mathrm{~T}_{2.2}$ & $\mathrm{~A}_{2.2}$ \\
\hline
\end{tabular}

Keterangan:

$\mathrm{T}_{1.1}$ : Hasil pretest kelas eksperimen 1

$\mathrm{T}_{2.1} \quad$ : Hasil posttest kelas eksperimen 1

$\mathrm{T}_{1.2}$ : Hasil pretest kelas eksperimen 2

$\mathrm{T}_{2.2}$ : Hasil posttest kelas eksperimen 2

$A_{1.1}$ : Perlakuan pembelajaran POGIL dengan animasi komputer.

$\mathrm{A}_{1.2}$ : Perlakuan pembelajaran konvensional

$\mathrm{A}_{2.1}$ : Hasil angket motivasi belajar kelas eksperimen 1

$\mathrm{A}_{2.2}$ : Hasil angket motivasi belajar kelas eksperimen 2

\section{Teknik Pengolahan Data}

Teknik statistik yang digunakan untuk uji hipotesis 1 adalah analisis statitstik berdasarkan rancangan penelitian semu faktorial 2 × 2 . Dengan rancangan penelitian ini semu faktorial 2 × 2 tersebut di tunjukkan dalam tabel 3 .

Tabel 3. Rancangan Penelitian Semu Faktorial 2 x 2

\begin{tabular}{ccc}
\hline Hasil Belajar & Kelompok Eksperimen 1 & Kelompok Eksperimen 2 \\
\hline Di atas rata-rata hitung & A1 & A2 \\
\hline Di bawah rata-rata hitung & B1 & B2 \\
\hline
\end{tabular}


Dengan uji chi kuadrat $\left(X^{2}\right)$ berdasarkan rancangan penelitian semu fatorial $2 \times 2$ tersebut, jika $X_{\text {hitung }}^{2} X_{(1-\alpha)(k-}$ 1) berarti pembelajaran POGIL animasi komputer berpengaruh positif terhadap hasil belajar siswa pada materi pokok Stoikiometri. Uji hipotesis ini dilakukan pada tingkat signifikansi 5\%. Selanjutnya untuk melihat perbandingan hasil belajar kimia siswa menggunakan uji t (uji pihak kanan). Untuk mengungkapkan masalah nomor 2 dilakukan uji hipotesis nomor 2 dengan cara yang sama dalam mengungkapkan masalah nomor 1 tersebut. Untuk menguji hipotesis nomor 3 (terdapat pengaruh motivasi yang ditimbulkan pembelajaran POGILanimasi komputer terhadap hasil belajar siswa pada materi pokok Stoikiometri). Rumusan hipotesis statistiknya adalah sebagai berikut:

$H o=\mu_{1} \leq \mu_{2}$

$H a=\mu_{1}>\mu_{2}$

$\mu_{1}=$ rata- rata hitung hasil posttest dari pretest kelompok kelas eksperimen 1.

$\mu_{2}=$ rata- rata hitung hasil posttest dari pretest kelompok kelas eksperimen 2.

\section{Hasil dan Pembahasan}

\section{Uji Coba Instrumen Tes Hasil Belajar}

a. Validitas tes

Soal yang diujicobakan sebanyak 30 soal yang diujikan pada 45 orang siswa, setelah dilakukan analisis ternyata diperoleh 24 soal yang valid dan 6 soal yang tidak valid, sehingga soal yang digunakan untuk mengukur hasil belajar siswa adalah 24 soal dalam bentuk pilihan berganda.

b. Reliabilitas tes

Dari 30 soal yang diujicobakan yang digunakan sebagai instrumen hasil belajar dihitung reliabilitas tes secara keseluruhan Dari perhitungan reliabilitas maka dapat dirumuskan bahwa soal instrumen tes ini Reliabel, karena diperoleh $\mathrm{r}_{11}$ sebesar 0,831 lebih besar dari $\mathrm{r}$ tabel $(0,294)$ dan dapat dinyatakan bahwa keseluruhan tes tersebut tergolong kategori reliabilitas tinggi.

c. Tingkat Kesukaran dan

Dari 30 soal yang diujicobakan yang digunakan sebagai instrumen hasil belajar memiliki tingkat kesukaran yaitu sukar 4 soal, sedang 22 soal dan mudah 4 soal.

d. Daya Pembeda Soal

Dari 30 soal yang diujikan yang digunakan sebagai instrumen hasil belajar memiliki daya pembeda. Perhitungan daya beda juga dilakukan terhadap soal instrumen tes, dan diperoleh data sebagai berikut : 10 soal memiliki daya beda baik, 14 soal memiliki daya beda cukup dan 6 soal memiliki daya beda jelak, dapat dilihat pada lampiran 10 dan lampiran 15. Sehingga disimpulkan dari 30 soal sebagai instrumen hasil belajar maka 24 soal diterima dan 6 soal di tolak. Maka instrumen soal yang digunakan sebanyak 24 soal.

\section{Deskripsi Data Hasil Penelitian}

Deskripsi data hasil penelitian dikelompokkan menjadi dua bagian yaitu: 1) data hasil belajar siswa yang menggunakan pembelajaran POGIL dengan animasi komputer, 2) data hasil belajar siswa menggunakan pembelajaran konvensional. Data hasil belajar siswa di jaring dengan menggunakan tes prestasi belajar stoikiometri menggunakan skor dan dikonversikan dalam nilai skala 0-100.

\section{Hasil Belajar Siswa}

Berdasarkan data hasil belajar siswa yang diperoleh dapat dilihat pada lampiran dan setelah data ditabulasikan maka diperoleh rata-rata hitung, standart deviasi, dan varians dari data pretest kelas eksperimen dan kelas konvensional di perlihatkan pada Tabel 4. 
Tabel 4. Rata-rata hitung, Standart deviasi, dan Varians Data Hasil Belajar

\begin{tabular}{lcccc}
\hline & \multicolumn{2}{c}{ Kelas Eksperimen 1 } & \multicolumn{2}{c}{ Kelas Ekpereimen 2 } \\
\cline { 2 - 5 } & Pretest & Posttest & Pretes & Posttes \\
\hline Rata - Rata $(\bar{X})$ & 28,4 & 85,2 & 29,9 & 74,4 \\
\hline Standart Deviasi (SD) & 8,5 & 6,6 & 8,33 & 8,15 \\
\hline Varians $\left(S^{2}\right)$ & 72 & 43,6 & 69,3 & 66,4 \\
\hline
\end{tabular}

\section{Hasil Motivasi Belajar Siswa}

Berdasarkan data pada lampirandiketahui motivasi belajar siswa diperoleh rata-rata hitung, standart deviasi, dan varians dari data angket motivasi kelas eksperimen dan kelas konvensional di perlihatkan pada Tabel 5.

Tabel 5. Rata-rata hitung, Standart deviasi, dan Varians Data Hasil Belajar

\begin{tabular}{lcc}
\hline & \multicolumn{2}{c}{ Motivasi } \\
\cline { 2 - 3 } & Kelas Eksperimen 1 & Kelas Eksperimen 2 \\
\hline Rata - Rata $(\bar{X})$ & 82,78 & 72,68 \\
\hline Standart Deviasi (SD) & 7,86 & 6,89 \\
\hline Varians $\left(\mathrm{S}^{2}\right)$ & 61,92 & 47,56 \\
\hline Jumlah Siswa $(\mathrm{n})$ & 40 & 40 \\
\hline
\end{tabular}

\section{Pengujian Syarat Analisis}

Selanjutnya untuk kedua kelompok dilakukan uji normalitas dan uji homogenitas data.

\section{Uji Normalitas Data}

Pengujian normalitas data dilakukan untuk mengetahui apakah data berdistribusi normal atau tidak. Untuk menguji normalitas data digunakan uji chi-kuadrat. Kriteria pengujian adalah jika $\chi^{2}$ hitung $<\chi_{\text {tabel }}^{2}$ maka data berdistribusi normal. Data hasil pengujian normalitas pretest dan posttest diperlihatkan pada tabel 6 . Perhitungan

Tabel 6. Hasil Uji Normalitas Data Siswa

\begin{tabular}{lcccc}
\hline \multicolumn{1}{c}{ Data } & Kelas & $\chi_{\text {hitung }}^{2}$ & $\chi_{\text {tabel }}^{2}$ & Keterangan \\
\hline Pretest & Eksperimen 1 & 4,742 & \multirow{2}{*}{11,07} & Berdistribusi Normal \\
\cline { 2 - 3 } & Eksperimen 2 & 4,162 & & Berdistribusi Normal \\
\hline Posttest & Eksperimen 1 & 4,825 & 11,07 & \\
\cline { 2 - 3 } & Eksperimen 2 & 5,388 & & \\
\hline
\end{tabular}

\section{Uji Homogenitas Data}

Pengujian homogenitas data dilakukan untuk mengetahui apakah sampel dari kedua kelompok eksperimen berasal dari populasi yang homogen dengan menguji data pretest dan posttest dengan uji kesamaan varians. Kriteria pengujian adalah $\mathrm{F}_{\text {hitung }}<\mathrm{F}_{\text {tabel }}$ maka data kedua kelas adalah kelas yang homogen. Data hasil pengujian homogenitas pretest dan posttest diperlihatkan dalam tabel 7. 
Tabel 7. Hasil Uji Homogenitas Data Siswa

\begin{tabular}{cccccc}
\hline Data & Kelas & Varians & $\mathrm{F}_{\text {hitung }}$ & $\mathrm{F}_{\text {tabel }}$ & Keterangan \\
\hline Pretest & Eksperimen 1 & 72,02 & \multirow{2}{*}{1,04} & \multirow{2}{*}{1,705} & Homogen \\
\cline { 2 - 3 } & Eksperimen 2 & 69,34 & & & Homogen \\
\hline Posttest & Eksperimen 1 & 43,58 & \multirow{2}{*}{1,52} & 1,705 & \\
\cline { 2 - 3 } & Eksperimen 2 & 66,37 & & & \\
\hline
\end{tabular}

\section{Uji Hipotesis 1}

Hipotesis 1, yakni hasil belajar siswa yang menggunakan pembelajaran POGIL dengan animasi komputer lebih tinggi di bandingkan dengan hasil belajar siswa yang menggunakan pembelajaran konvensional yang di uji menggunakan uji statistik uji beda nyata uji satu pihak yaitu uji pihak kanan. Kriteria pengujian $Z_{\text {hitung }}>Z_{\text {tabel. }}$ Data uji hipotesis 1, diperlihatkan pada tabel 8. di bawah ini.

Tabel 8. Hasil Uji Hpotesis 1

\begin{tabular}{cccc}
\hline Data & $Z_{\text {hitung }}$ & $Z_{\text {tabel. }}$ & Keterangan \\
\hline Hasil Belajar Siswa & 6,51 & 1,71 & Ha diterima dan H0 ditolak \\
\hline
\end{tabular}

Berdasarkan perhitungan di peroleh $Z_{\text {hitung }}>Z_{\text {tabel }}$ yaitu, 6,51 $>1,71$. Dengan demikian berarti hasil belajar siswa yang menggunakan pembelajaran POGIL dengan animasi komputer lebih tinggi dari pada hasil belajar siswa yang menggunakan pembelajaran konvensional pada materi pokok Stoikiometri.

\section{Uji Hipotesis 2}

Hipotesis 2, yakni motivasi belajar siswa yang menggunakan pembelajaran POGIL dengan animasi komputer lebih tinggi di bandingkan pembelajaran konvensional yang di uji menggunakan uji statistik uji beda nyata uji satu pihak yaitu uji pihak kanan. Kriteria pengujian $Z_{\text {hitung }}>Z_{\text {tabel. }}$ Data uji hipotesis 2, diperlihatkan pada tabel 9.

Tabel 9. Hasil Uji Hpotesis 2

\begin{tabular}{cccc}
\hline Data & $\mathrm{Z}_{\text {hitung }}$ & $\mathrm{Z}_{\text {tabel. }}$ & Keterangan \\
\hline Motivasi Belajar Siswa & 6,10 & 1,71 & Ha diterima dan H0 ditolak \\
\hline
\end{tabular}

Berdasarkan perhitungan di peroleh $Z_{\text {hitung }}>Z_{\text {tabel }}$ yaitu, 6,10>1,71. Dengan demikian berarti motivasi belajar siswa yang menggunakan pembelajaran POGIL dengan animasi komputer lebih tinggi dari pada hasil belajar siswa yang menggunakan pembelajaran konvensional pada materi pokok Stoikiometri.

\section{Uji Hipotesis 3}

Hipotesis 3, yakni terdapat pengaruh motivasi yang ditimbulkan pada pembelajaran POGIL dengan menggunakan animasi komputer terhadap hasil belajar siswa . Hipotesis ini di uji menggunakan uji regresi linear. Kriteria pengujian $F_{\text {hitung }}>F_{\text {tabel. }}$ Data uji hipotesis 3, diperlihatkan pada tabel 10.

Tabel 10. Hasil Uji Hpotesis 3

\begin{tabular}{ccccc}
\hline Uji & Data & $F_{\text {hitung }}$ & $F_{\text {tabel. }}$ & Keterangan \\
\hline Regresi Linear & $\begin{array}{c}\text { Hasil Belajar } \\
\text { MotivasiBelajar }\end{array}$ & 11,2 & 4,10 & Ha diterima dan H0 ditolak \\
& & & \\
\hline
\end{tabular}


Berdasarkan perhitungan seperti pada lampiran di peroleh $F_{\text {hitung }}>F_{\text {tabel }}$ yaitu, 11,2 > 4,10. Dengan demikian berarti terdapat pengaruh motivasi yang ditimbulkan pada pembelajaran POGIL dengan animasi komputer terhadap hasil belajar siswa. Kontribusi motivasi belajar kimia siswa adalah $72 \%$ sedangkan $28 \%$ disebabkan oleh faktor pendukung lain.

\section{Pembahasan Hasil Penelitian}

Berdasarkan hasil penelitian yang dilakukan bahwa siswa yang diajar menggunakan POGIL animasi komputer mendapatkan skor rata-rata 85,2, dan yang diajar menggunakan pembelajaran konvensioanal mendapatkan skor ratarata hasil belajar 74,4. Berdasarkan hasil ini dan pengujian hipotesis yang telah dilakukan diperoleh kesimpulan bahwa hasil belajar kimia siswa yang diajar dengan menggunakan POGIL animasi komputer lebih tinggi dari pada hasil belajar kimia siswa yang di ajar menggunakan pembelajaran konvensional.

Pembelajaran yang dilakukan dengan metode apa saja diharapkan dapat meningkatkan motivasi belajar siswa, tidak terkecuali pembelajaran POGIL dengan menggunakan animasi komputer dan pembelajaran konvensional. Berdasarkan hasil angket motivasi yang diperoleh dalam penelitian yang dilakukan bahwa motivasi belajar siswa yang diajar menggunakan POGIL animasi komputer mendapatkan skor rata-rata 82,78 dan motivasi belajar siswa yang diajar menggunakan pembelajaran konvensionl mendapatkan skor rata-rata 72,68. Siswa yang diajar menggunakan POGIL animasi komputer lebih tinggi motivasinya bila dibandingkan siwa yang diajar menggunakan pembelajaran konvensional.

Dari hasil penelitian ini kita dapat melihat dengan nyata bahwa pembelajaran POGIL dengan menggunakan animasi komputer dapat memberikan pengaruh positif yang cukup signifikan terhadap hasil belajar siswa. Hal ini sejalan dengan peneliti-peneliti sebelumnya yang telah berhasil membuktikan bahwa pembelajaran POGIL animasi dapat meningkatkan motivasi dan hasil belajar siswa. Dan dapat dilihat dari kontribusi motivasi belajar kimia siswa adalah $72 \%$.

Pemahaman siswa terlihat dari banyaknya soal jenis $\mathrm{C} 4$ yang dapat terjawab yaitu $74 \%$ pada pembelajaran POGIL dengan animasi komputer, sedangkan pada pembelajaran konvensional sebesar $58 \%$, dari data tersebut dapat disimpulkan bahwa siswa dapat menerima dengan baik pembelajaran POGIL dengan animasi komputer. Dan dapat diterapkan dalam penyelesaian soal-soal yang diberikan.

Berdasarkan pengumpulan data dan pengolahan data statisik yang dilakukan di SMA Negeri 1 Panombeian Panei Kabupaten Simalungun, diperoleh temuan penelitian strategi pembelajaran POGIL dengan animasi komputer dapat meningkatkan motivasi belajar siswa. Penerapan pembelajaran POGIL animasi komputer dapat merangsang siswa dalam menemukan masalah dibandingkan dengan penerapan pembelajaran konvensional.

\section{Kesimpulan}

Berdasarkan pengolahan data dan pembahasan hasil penelitian yang dilakukan, dapat ditarik kesimpulan sebagai berikut:

1. Hasil belajar siswa yang diajar menggunakan pembelajaran POGIL dengan animasi komputer lebih tinggi dari pada siswa yang diajar menggunakan pembelajaran konvensional.

2. Motivasi belajar siswa yang diajar menggunakan POGIL dengan animasi komputer lebih tinggi dari pada siswa yang diajar menggunakan pembelajaran konvensional.

3. Terdapat pengaruh motivasi yang ditimbulkan pembelajaran POGIL animasi komputer terhadap hasil belajar siswa pada materi pokok stoikiometri, dan tedapat kontribusi antara motivasi belajar dan hasil belajar siswa sebagai akibat dari pembelajaran POGIL dengan animasi komputer sebesar $72 \%$. 


\section{Ucapan Terima Kasih}

Terima kasih penulis ucapkan kepada Prodi Program Pascasarjana Magister (S2) Pendidikan Kimia Universitas Negeri Medan atas Fasilitas yang diberikan dalam menunjang Proses studi dan penelitian. Ucapan terima kasih juga penulis sampaikan kepada Dosen Pembimbung dan Guru Kimia SMA Negeri 1 Panombeian Panei Kabupaten Simalungun yang telah membantu dalam pelaksanaan penelitian.

\section{Referensi}

[1] Altun, (2009), Developing an interactive virtual chemistry laboratory enriched with constructivist learning activities for secondary schools, World Conference on Educational Sciences 2009, Procedia Social and Behavioral Sciences (1): 1895-1898

[2] Butar-Butar, R. (2007). Pengaruh Penggunaan Program Animasi Komputer Terhadap Motivasi Dan Hasil Belajar Kimia Siswa SMA Negeri di Kota Sibolga. Tesis Pascasarjana Unimed.

[3] Sanjaya,W. 1997.Strategi Pembelajaran.Jakarta

[4] Richard S. Moog, Frank J. Creegan and Troy Wolfskill, (2009), POGIL: Process-Oriented Guided-Inquiry Learning, Chemists' Guide to Effective TeachingVolume II, 99-101, Upper Saddle River, New Jersey 07458, USA.

[5] Hanson, D. (2006). Instructors Guide to Process-Oriented Guided-Inquiry Learning. Lisle, IL: Pacific Crest.

[6] Erik, M. and Derrik, H., (2010) Using POGIL Techniques in an Information Literacy Curriculum, Wake Forest University, Winston Salem, NC 27106, USA.

[7] Farrell,J. J., Moog, R. S., and Spencer, J. N. (1999). A guided inquiry general chemistry course. J. Chem. Educ., 76, 570-574. 